\title{
Grazing capacity, milk production and milk composition of kikuyu over-sown with annual or perennial ryegrass
}

\author{
Janke van der Colf ${ }^{1,2 *}$, Philip R Botha ${ }^{1}$, Robin Meeske ${ }^{1}$ and Wayne F Truter $^{2}$ \\ ${ }^{1}$ Western Cape Department of Agriculture, Outeniqua Research Farm, George, South Africa \\ ${ }^{2}$ Department of Plant Production and Soil Science, University of Pretoria, Pretoria, South Africa \\ * Corresponding author, e-mail: JankeVdC@elsenburg.com
}

\begin{abstract}
Kikuyu (Pennisetum clandestinum) is a highly productive pasture species that supports high stocking rates and milk production per hectare, but production per cow is low due to low nutritive value. The aim of this study was to determine the grazing capacity, milk production and milk composition of dairy cows grazing irrigated kikuyu over-sown with Italian (Lolium multiflorum var. italicum), Westerwolds (L. multiflorum var. westerwoldicum) or perennial ryegrass ( $L$. perenne) during autumn. The grazing capacity of the kikuyu-ryegrass systems was lower during winter and autumn than during spring and summer, with the seasonal grazing capacity of the perennial ryegrass treatment more evenly distributed than that of the Italian and Westerwolds ryegrass treatments. The perennial ryegrass treatment had a lower butterfat and milk production per lactation than the Italian and Westerwolds ryegrass treatments, but had the highest milk solids and fat corrected milk production per hectare. The latter was a result of the higher annual grazing capacity achieved by the perennial ryegrass treatment. It was concluded that because kikuyu over-sown with perennial ryegrass supported a higher number of animals and had a more evenly distributed fodder-flow, it achieved higher animal production per hectare than kikuyu over-sown with annual ryegrass varieties.
\end{abstract}

Keywords: fat-corrected milk, Lolium, milk solids, pasture, Pennisetum clandestinum

\section{Introduction}

There is a continuing trend for higher milk production from pasture-based areas than systems based on total mixed rations in South Africa. Milk production density is specifically high in areas such as the coastal regions of the Western Cape and Eastern Cape provinces (Coetzee 2014). Within pasture-based systems for dairy production the focus is always on producing sufficient pasture of a high nutritive value to ensure that production per animal and per hectare can be optimised. With pastures in the Southern Cape that are predominately based on kikuyu (Pennisetum clandestinum) over-sown with temperate species, this challenge is complicated by some of the inherent characteristics and deficiencies of kikuyu. These include highly seasonal production patterns with high summer and autumn production, but low winter and spring production, challenges with optimum utilisation, low nutritive value compared with temperate pasture species and comparatively low milk production per cow (Marais 2001; García et al. 2014). Supplementation with concentrates is a possible means of improving the milk production of dairy cows grazing kikuyu (Reeves et al. 1996; García et al. 2014). The degree to which supplementation can be utilised in pasture systems is, however, limited by factors such as a diminishing return on concentrate feeding, decreased pasture intake and decreased efficiency of forage utilisation as the level of concentrate feeding increases (Caton and Dhuyvetter 1997; Meeske et al. 2006; Fulkerson et al. 2006).
An alternative to supplementation would be to maintain high pasture utilisation and pasture quality (van Houtert and Sykes 1999) of kikuyu pastures. The over-sowing of established kikuyu pastures with temperate grass species can provide more even seasonal fodder availability and, as a result, less variation in seasonal milk production and grazing capacity than pure kikuyu-based pastures (Botha et al. 2008b). Although kikuyu-ryegrass systems have been shown to have a lower nutritional value and require higher inorganic nitrogen inputs than kikuyu-clover systems, they have the advantage of higher dry matter production and are comparatively easy to manage (Botha et al. 2008a). However, producers in the southern Cape have to make a decision on which ryegrass species or variety to over-sow into their kikuyu pasture during autumn due to differing production patterns of these species. Autumn-established Italian and Westerwolds ryegrass in the region have similar yields during winter, but Italian ryegrass tends to have a higher yield during spring (Botha and Zulu 2013; Zulu et al. 2014). Perennial ryegrass can produce up to $13.7 \mathrm{t} \mathrm{DM} \mathrm{ha}^{-1} \mathrm{y}^{-1}$ in the Southern Cape, but poor persistence results in a decline in yield after the first year of production (van der Colf and Botha 2014). Although the seasonal and total pasture production potential in association with nutritive value are important factors that can affect this decision, Clark (2010) highlighted the fact that increased pasture yield achieved by the selection of alternative pasture species does not necessarily equate 
to a higher milk production per hectare. This is due to the compounding impact of various other factors, such as seasonal variation in nutritive value, stocking rate and unique management challenges of different systems. It is thus important that pasture systems based on over-sowing kikuyu with different species or varieties of ryegrass be evaluated to quantify the impact on production per animal, grazing capacity and animal production per hectare. The aim of this study was to compare the grazing capacity, milk production potential and milk composition of Jersey cows grazing kikuyu over-sown with Italian (Lolium multiflorum var. italicum), Westerwolds (L. multiflorum var. westerwoldicum) or perennial ryegrass (L. perenne).

\section{Materials and methods}

\section{Experimental site and layout}

The study was conducted over a period of two years as part of a system trial on approximately 9 ha of existing kikuyu on the Outeniqua Research Farm (33 ${ }^{\circ} 58^{\prime} 38^{\prime \prime} \mathrm{S}$, $22^{\circ} 25^{\prime} 16^{\prime \prime} \mathrm{E}$; altitude $201 \mathrm{~m}$ ) near George in the Western Cape province of South Africa. A comprehensive description of the experimental site, climatic data, pasture treatments, pasture management and pasture parameters including dry matter production, botanical composition and nutritive value of the systems evaluated can be found in van der Colf et al. (2015).

The experimental area was divided into 24 experimental paddocks (approximately 0.38 ha paddock ${ }^{-1}$ ), which were in turn divided into eight blocks, each consisting of three paddocks apiece. The three experimental paddocks within a block were randomly allocated to one of the three pasture treatments under investigation, resulting in a total number of eight experimental paddocks per treatment.

\section{Treatments and establishment methods}

The three treatments consisted of kikuyu over-sown with Italian ryegrass 'Jeanne', Westerwolds ryegrass 'Jivet' and perennial ryegrass 'Bronsyn'. Planting dates and methods are based on the ability of a species to compete with kikuyu during establishment (Botha 1995). The Italian and perennial ryegrass was established once the kikuyu had been grazed down to $50 \mathrm{~mm}$, followed by mulching (1.6 $\mathrm{m}$ Nobilli with 24 blades) the remaining stubble and then planting the ryegrass with an Aitchison seeder $(2.4 \mathrm{~m}$ Aitchison 3116C Seedmatic with 16 rows) (Botha et al. 2008a). The Italian ryegrass and perennial ryegrass were planted at seeding rates of 25 and $20 \mathrm{~kg} \mathrm{ha}^{-1}$, respectively. The Westerwolds ryegrass was established by grazing kikuyu to $50 \mathrm{~mm}$, broadcasting the seed onto the stubble at a rate of $25 \mathrm{~kg} \mathrm{ha}^{-1}$ and mulching the pasture to ground level (Botha 2003). This method was found to be the most economical method for establishment of Westerwolds ryegrass into kikuyu, with yield similar to when it was established using a planter (Botha 2003). The planter is used for perennial ryegrass and Italian ryegrass to ensure adequate contact between the soil and seeds, due to the lower seedling vigour compared to Westerwolds ryegrass (Botha 2009). All pasture treatments were rolled with a $2.33 \mathrm{~m}$ Cambridge roller after planting was completed. The annual ryegrass varieties were over-sown during March
(Botha 1995; Botha and Zulu 2013). Perennial ryegrass was over-sown a month later during April to ensure the competition from kikuyu was lowered for the less vigorous seedlings of this species (Botha 1995). All treatments were re-established according to the same methods during year 2 . The perennial ryegrass was re-established due to its poor persistence into the second year after establishment as is common to this region (Botha et al. 2008c).

\section{Pasture management and measurement}

Irrigation scheduling was conducted using tensiometer readings, which were taken daily at 08:00 in the morning. The tensiometers were located at strategic points throughout the experimental area at a depth of $150 \mathrm{~mm}$. Irrigation commenced at a tensiometer reading of $-25 \mathrm{kPa}$ and was terminated at a reading of $-10 \mathrm{kPa}$ (Botha 2002). Lower than average rainfall during December and January in year 2, accompanied by a shortage of available irrigation water, resulted in irrigation below optimum levels during January and February (van der Colf et al. 2015). Fertiliser was applied according to annual soil samples taken at a depth of $100 \mathrm{~mm}$ (Miles 1997) and recommendations for pastures in the region (Beyers 1973). All the treatments were top-dressed at a rate of $55 \mathrm{~kg} \mathrm{~N} \mathrm{ha}^{-1}$ month $^{-1}$ with limestone ammonium nitrate (Marais 2001; Botha 2003).

Dry matter (DM) production was estimated using a rising plate meter (Stockdale 1984; Fulkerson 1997). A detailed description on how the rising plate meter was calibrated and used, the monthly growth rates, seasonal DM production, annual DM production and nutritive value for the treatments during the two-year experimental period are reported in van der Colf et al. (2015).

\section{Experimental animals}

Forty-five multiparous Jersey cows from the Outeniqua Research Farm herd, used during the experimental period, were blocked according to calving date, lactation number and $4 \%$ fat corrected milk (FCM) production for the previous lactation. Cows within blocks were randomly allocated to the three pasture treatments, resulting in 15 core cows per treatment. Cows grazed the same treatment for the duration of a full lactation (305 d), with new cows allocated to each treatment during the second year of the study.

Cows were inseminated when on heat $50 \mathrm{~d}$ after calving and dried off $60 \mathrm{~d}$ before the expected calving date. For the Italian ryegrass-kikuyu and Westerwolds ryegrasskikuyu treatments, the experimental animals were on the study from June until March, whereas the animals for the perennial ryegrass-kikuyu treatment were on the study from July until April. The animals on the perennial ryegrasskikuyu treatment calved a month later than the animals on the Westerwolds ryegrass-kikuyu and Italian ryegrasskikuyu pasture treatments. The reason for this was that the perennial ryegrass-kikuyu pastures were established a month later than Italian ryegrass-kikuyu and Westerwolds ryegrass-kikuyu pastures and, as a result, they were only ready for grazing a month later. This would result in the perennial ryegrass treatment being grazed a month less in the winter period when pasture supply can be challenging, but a month longer in autumn when pasture availability is limited due to annual ryegrass being over-sown. 


\section{Grazing management and determination of grazing capacity}

The cows grazed the pasture treatments according to a 'put-and-take system' (Bransby and Tainton 1977). This system consisted of adding additional cows to groups when pasture production exceeded demand and removing cows when pasture demand exceeded pasture production. Milk production data was only collected for the 15 core treatment cows allocated per treatment. Experimental animals that could not be accommodated on the experimental area were kept on similar pastures until pasture production was such as to permit their return to the experimental area. This system allowed for the determination of grazing capacity of each treatment. Pasture was allocated according to dry matter production per grazing strip (determined with the rising plate meter) at a pasture allowance of $9 \mathrm{~kg}$ DM pasture $\mathrm{d}^{-1}$ or $4.5 \mathrm{~kg}$ DM pasture per grazing above $30 \mathrm{~mm}$. In addition to roughage provided through pasture, animals received $4 \mathrm{~kg}$ (as is) of a maize-based dairy concentrate (11.9 MJ metabolisable energy and $12 \%$ crude protein), which was fed at a rate of $2 \mathrm{~kg}$ per milking.

Each treatment consisted of eight experimental paddocks that were divided into two grazing strips by a permanent one-metre-high fence. Grazing strips were separated into four blocks by a temporary electric fence. After each milking, or twice daily, animals received a fresh block of pasture.

Animals grazed each grazing strip for two consecutive days and each experimental paddock for $4 \mathrm{~d}$. Cows were on the experimental area for a total of $32 \mathrm{~d}$ per grazing cycle. However, while one block was being grazed, the other seven were rested, resulting in a 28-day period of absence from each block and a 30-day period of absence from each grazing strip. Cows could graze back for a maximum of $2 \mathrm{~d}$, after which the strip was closed up after they had moved to the new strip. The number of animals was adjusted according to available dry matter every second day, or the morning before they entered the new grazing strip.

\section{Milk production and milk composition}

Milk production and milk composition data was only collected for the 15 core cows allocated to each treatment. Cows were milked twice daily at 07:30 and 15:00, with a 20 point Dairymaster swing-over milking machine (Total Pipeline Industries, Heidelberg, South Africa). The machine was fully automated with weigh-all electronic milk meters that allowed daily milk production of each individual cow to be measured.

From the daily milk production data collected, the 305-day milk production of each cow was recorded. If a cow did not complete her full 305-day lactation (because she was dried off or the trial had ended), the milk production for the remaining days was calculated from a polynomial equation developed from her milk production data up to that point. The polynomial equation, $y=a x^{2}+b x+c$, related daily milk production to days in lactation for a specific cow, where $y=$ daily milk yield $\left(\mathrm{kg} \mathrm{cow}{ }^{-1}\right), x=$ days in lactation, $a=$ factor $1, b=$ factor 2 and $c=$ a constant. Unique values for $a, b$ and $c$ were developed for each individual cow.

Milk composition was determined on a monthly basis from a $24 \mathrm{~mL}$ composite morning and afternoon milk sample of $16 \mathrm{~mL}$ and $8 \mathrm{~mL}$, respectively. The volume to be taken was calculated according the milking interval of $16 \mathrm{~h}$ for the morning milking and $8 \mathrm{~h}$ for the afternoon milking. Analysis was done a maximum of $2 \mathrm{~d}$ after sampling, before which samples were preserved in sodium dichromate. The protein, butterfat (BF), lactose and milk urea nitrogen (MUN) content of the milk was determined according to the IDF standard 141B (IDF 1996) with a Milkoscan FT 6000 analyser (Foss Electric, Hillerød, Denmark). Samples were also analysed for somatic cell count by means of cytometry using a Fossmatic 5000 (Foss Electric).

The 305-day lactation data and BF percentage of each cow was used to calculate FCM production by means of the equation $\mathrm{FCM}=\left(0.4{ }^{*} 305\right.$-day milk production $)+$ $\left(15^{\star} 305\right.$-day milk production*BF). The yield of butterfat ( $k g$ BF cow ${ }^{-1}$ ), protein ( $k g$ protein $\mathrm{cow}^{-1}$ ) and milk solids (kg MS cow ${ }^{-1}$ ) was calculated for the 305-day lactation of each cow and the mean production per treatment determined.

The mean daily milk yield for each treatment as calculated from the 15 core cows allocated per treatment was used alongside the recorded daily stocking rate per treatment (cows ha-1) to calculate milk production, FCM production and milk solids production per hectare of all three treatments. The milk production of additional cows that were placed on the trial area during periods when pasture supply exceeded demand of the 15 treatment cows was not used. When pasture demand exceeded supply, core treatment cows were placed on similar pastures and their milk production data still recorded.

\section{Body weight and body condition score}

Core treatment cows were weighed and condition scored at calving, and on a monthly basis thereafter, after the morning milking. Condition scoring was done by the same individual throughout the trail period according to a five-point body condition scoring system (Roche et al. 2004). Animals were also weighed and condition scored at the end of the study or when a specific cow was dried off. The start and end data was used to calculate the mean change in bodyweight and body condition score (BCS) of the treatments at the end of the study.

\section{Statistical design}

The statistical design for pasture production and grazing capacity measurements was a randomised complete block design with the three treatments randomly allocated within each of the eight experimental blocks. The grazing capacity data was summarised over months, seasons and years. Seven different linear models were fitted to the data. The basic analysis was for each date comparing the treatment effects, then averaged over month for each season and year, comparing season averages in a specific year, averages over seasons in a specific year and lastly averages over years comparing treatments. Season, year or both were added as a subplot factor in the combined models to accommodate the repeated measurements over time (Little and Hills 1978).

A randomised block design was implemented for animal production data including milk production, milk component analyses, BW and BCS. Forty-five core treatment cows were divided into 15 blocks (three cows per block) according 
to calving date, 4\% FCM production from previous lactation and lactation number. Within each block, the cows were randomly assigned to the treatments.

The data were subjected to a repeated measures analysis of variance (ANOVA) using PROC GLM of the SAS software (SAS 1999) to identify significant treatment effects. The Shapiro-Wilk test (Shapiro and Wilk 1965) was performed to test normality of residuals and Fisher's $t$-LSD (least significant difference) was calculated at the $5 \%$ significance level to compare treatment means.

\section{Results and discussion}

\section{Monthly and seasonal grazing capacity}

The monthly grazing capacity of kikuyu over-sown with Italian, Westerwolds and perennial ryegrass during years 1 and 2 is shown in Table 1 and Table 2, respectively. During the period after establishment, when animals could not graze pastures, stocking rates were recorded as zero.

The lowest grazing capacities occurred between the winter months of June and August during the two years. The grazing capacities of all three kikuyu-ryegrass pastures were similar $(P>0.05)$ within months from July to September during year 1 and from June to July during year 2. During June 2007 and May 2008 there were no cows grazing the perennial ryegrass-kikuyu pasture, whilst the grazing capacities of Italian ryegrass and Westerwolds ryegrasskikuyu did not differ $(P>0.05)$ during these months.

The grazing capacity for the Italian ryegrass-kikuyu pasture during October was similar $(P>0.05)$ to grazing capacities from November to February, but higher $(P<0.05)$ than the rest of the months during year 1 . During year 2 the grazing capacity during October was higher $(P>0.05)$ than for other months when kikuyu was over-sown with Italian ryegrass. Highest grazing capacities for Italian ryegrasskikuyu were thus distributed mainly within spring.

The Westerwolds ryegrass-kikuyu had a higher $(P<0.05)$ grazing capacity during January and February than other months during year 1 . During year 2 the grazing capacity of Westerwolds ryegrass-kikuyu during December and January

Table 1: Monthly grazing capacity (cows ha ${ }^{-1}$ ) of kikuyu over-sown with Italian, Westerwolds and perennial ryegrass for year 1 . Means with no common superscript letters differed significantly at $P<0.05$. LSD (0.05) compares over treatments and months

\begin{tabular}{llcl}
\hline Month & $\begin{array}{c}\text { Italian- } \\
\text { kikuyu }\end{array}$ & $\begin{array}{c}\text { Westerwolds- } \\
\text { kikuyu }\end{array}$ & $\begin{array}{c}\text { Perennial- } \\
\text { kikuyu }\end{array}$ \\
\hline June & $6.10^{\text {ghijk }}$ & $5.71^{\text {hijkl }}$ & $0^{q}$ \\
July & $3.09^{\mathrm{op}}$ & $2.65^{\mathrm{p}}$ & $3.16^{\mathrm{op}}$ \\
August & $3.88^{\mathrm{no}}$ & $4.07^{\mathrm{mno}}$ & $4.49^{\mathrm{mm}}$ \\
September & $6.29^{\mathrm{fghij}}$ & $5.64^{\mathrm{hijkl}}$ & $5.42^{\mathrm{jkk}}$ \\
October & $8.17^{\mathrm{cd}}$ & $6.42^{\mathrm{fghij}}$ & $6.75^{\mathrm{efgh}}$ \\
November & $7.47^{\mathrm{def}}$ & $5.52^{\mathrm{ijkl}}$ & $7.05^{\mathrm{defg}}$ \\
December & $7.77^{\mathrm{cde}}$ & $7.49^{\mathrm{def}}$ & $8.93^{\mathrm{bc}}$ \\
January & $7.02^{\mathrm{defg}}$ & $9.45^{\mathrm{ab}}$ & $8.71^{\mathrm{bc}}$ \\
February & $7.90^{\mathrm{cde}}$ & $10.29^{\mathrm{a}}$ & $9.51^{\mathrm{ab}}$ \\
March & $6.54^{\mathrm{fghi}}$ & $7.78^{\mathrm{cde}}$ & $7.39^{\mathrm{def}}$ \\
April & $0^{\mathrm{q}}$ & $0^{\mathrm{q}}$ & $6.04^{\mathrm{ghijkl}}$ \\
May & $5.06^{\mathrm{klmn}}$ & $5.21^{\mathrm{jklm}}$ & $0 \mathrm{q}$ \\
LSD (0.05) & & 1.22 & \\
\hline
\end{tabular}

were similar $(P<0.05)$ to March, but higher $(P>0.05)$ than the rest of the months. Thus the maximum number of animals were supported in this pasture system primarily during summer.

The highest $(P>0.05)$ and similar $(P<0.05)$ to the highest grazing capacities for perennial ryegrass-kikuyu were between December and February during year 1 and between October and December during year 2. The highest grazing capacities for kikuyu over-sown with perennial ryegrass were thus distributed between spring and summer.

The grazing capacity of Italian ryegrass-kikuyu was higher $(P>0.05)$ than that of Westerwolds ryegrasskikuyu during October and November during both years. Westerwolds ryegrass-kikuyu had a higher grazing capacity than Italian ryegrass-kikuyu from January to March in year 1 and from December to March in year 2. During year 1 the perennial ryegrass-kikuyu had a similar grazing capacity to the highest $(P>0.05)$ value within all months, with the exception of October, June and May. June and May coincided with the period when perennial ryegrass was being over-sown or not yet grazed, respectively.

The mean seasonal grazing capacity of kikuyu over-sown with Italian, Westerwolds or perennial ryegrass during years 1 and 2 is shown in Table 3 . In order to calculate seasonal grazing capacity, stocking rates were recorded as zero during periods when pastures were not being grazed. These periods coincided with the time when animals could not graze pastures after ryegrass had been established during autumn (see Tables 1 and 2).

The seasonal grazing capacity of all kikuyu-ryegrass pastures was lower during winter and autumn than during spring and summer. Low winter grazing capacities were primarily attributed to low winter growth rates of pastures (van der Colf et al. 2015), while lowered autumn grazing capacities were due to pastures being over-sown during autumn on an annual basis and not being grazed for the full season (Tables 1 and 2). An exception was the perennial ryegrass-kikuyu pasture, which had a lower winter grazing capacity during year 1 because grazing was initiated a month later than for the other pastures.

Table 2: Monthly grazing capacity (cows ha ${ }^{-1}$ ) of kikuyu over-sown with Italian, Westerwolds and perennial ryegrass for year 2 . Means with no common superscript letters differed significantly at $P<0.05$. LSD (0.05) compares over treatments and months

\begin{tabular}{llll}
\hline Month & $\begin{array}{l}\text { Italian- } \\
\text { kikuyu }\end{array}$ & $\begin{array}{c}\text { Westerwolds- } \\
\text { kikuyu }\end{array}$ & $\begin{array}{c}\text { Perennial- } \\
\text { kikuyu }\end{array}$ \\
\hline June & $3.22^{\text {op }}$ & $3.20^{\text {op }}$ & $3.96^{\text {mno }}$ \\
July & $3.79^{\text {mno }}$ & $3.46^{\text {nop }}$ & $2.88^{\mathrm{p}}$ \\
August & $4.37^{\mathrm{klm}}$ & $4.40^{\mathrm{jklm}}$ & $4.92^{\mathrm{hjk}}$ \\
September & $5.21^{\mathrm{ghij}}$ & $4.64^{\mathrm{jkl}}$ & $5.86^{\mathrm{efg}}$ \\
October & $7.41^{\mathrm{ab}}$ & $5.28^{\mathrm{ghi}}$ & $7.62^{\mathrm{a}}$ \\
November & $6.55^{\mathrm{cde}}$ & $5.64^{\mathrm{fgh}}$ & $7.46^{\mathrm{ab}}$ \\
December & $5.99^{\mathrm{defg}}$ & $7.65^{\mathrm{a}}$ & $7.53^{\mathrm{ab}}$ \\
January & $5.66^{\mathrm{fgh}}$ & $7.83^{\mathrm{a}}$ & $6.74^{\mathrm{bcd}}$ \\
February & $5.36^{\mathrm{ghi}}$ & $6.46^{\mathrm{cdef}}$ & $5.89^{\mathrm{efg}}$ \\
March & $6.36^{\mathrm{cdef}}$ & $7.18^{\mathrm{abc}}$ & $6.32^{\mathrm{def}}$ \\
April & $0^{\mathrm{q}}$ & $0 \mathrm{q}$ & $4.22^{\mathrm{klmn}}$ \\
LSD $(0.05)$ & & 0.829 & \\
\hline
\end{tabular}


The Italian ryegrass-kikuyu did not achieve the highest $(P>0.05)$ or similar $(P<0.05)$ to the highest seasonal grazing capacity during any of the seasons. It did, however, have a higher $(P>0.05)$ grazing capacity during spring than Westerwolds ryegrass-kikuyu during both years. The Westerwolds ryegrass-kikuyu had a higher $(P>0.05)$ summer grazing capacity than Italian ryegrass-kikuyu during summer. The perennial ryegrass-kikuyu showed a similar $(P<0.05)$ seasonal pattern in grazing capacity to Westerwolds ryegrass-kikuyu during year 1 , with lower $(P>0.05)$ grazing capacities than Italian ryegrass-kikuyu during spring, but higher $(P>0.05)$ during summer. Irrespective of this trend, perennial ryegrass-kikuyu maintained a higher numerical grazing capacity than the lowest grazing capacity from spring to autumn. During year 2, kikuyu over-sown with perennial ryegrass on an annual basis had a higher $(P>0.05)$ seasonal grazing capacity than the other two kikuyu-ryegrass systems from spring to autumn.

The monthly grazing capacities of kikuyu over-sown with annual or perennial ryegrass varied between 2.65 and 10.3 cows ha ${ }^{-1}$ during year 1 (Table 1 ) and between 2.88 and 7.83 cows ha-1 during year 2 (Table 2). The variation in grazing capacity over months and seasons highlights one of the main challenges that producers who have kikuyuryegrass pastures experience, namely how to manage the large seasonal variation in pasture supply. This variation in monthly grazing capacity should form the basis of fodderflow planning within any kikuyu-ryegrass-based system, since the ryegrass species or variety over-sown into kikuyu affected the seasonal distribution of grazing capacity. If the aim is to carry a high number of animals during spring, the Italian ryegrass-kikuyu pastures were superior, whereas the Westerwolds ryegrass-kikuyu pasture shifted maximum grazing capacities to summer. The perennial ryegrass-kikuyu system showed the most even distribution of grazing capacity of the three pasture systems. It is, however, unlikely that over-sowing all kikuyu-based pastures on a farm with one species or variety would be the best strategy. By allocating specific areas to specific ryegrass species and adequately dispersing planting dates from late summer to late autumn (Botha and Zulu 2013) when over-sowing kikuyu, producers will be able to more effectively disperse pasture production over seasons. For

Table 3: Mean seasonal grazing capacity (cows ha-1) of kikuyu over-sown with Italian, Westerwolds and perennial ryegrass during years 1 and 2. LSD (0.05) compares over season and treatment within year. Means with no common superscript letters differed significantly at $P<0.05$

\begin{tabular}{llcccc}
\hline Year & Season & $\begin{array}{c}\text { Italian- } \\
\text { kikuyu }\end{array}$ & $\begin{array}{c}\text { Westerwolds- } \\
\text { kikuyu }\end{array}$ & $\begin{array}{c}\text { Perennial- } \\
\text { kikuyu }\end{array}$ & $\begin{array}{c}\text { LSD } \\
(0.05)\end{array}$ \\
\hline 1 & Winter & $4.37^{\mathrm{d}}$ & $4.11^{\mathrm{d}}$ & $2.36^{\mathrm{e}}$ & 0.704 \\
& Spring & $7.43^{\mathrm{b}}$ & $5.90^{\mathrm{c}}$ & $6.44^{\mathrm{c}}$ & \\
& Summer & $7.59^{\mathrm{b}}$ & $9.10^{\mathrm{a}}$ & $9.09^{\mathrm{a}}$ & \\
& Autumn & $3.95^{\mathrm{d}}$ & $4.34^{\mathrm{d}}$ & $4.34^{\mathrm{d}}$ & \\
2 & Winter & $3.75^{\mathrm{ef}}$ & $3.64^{\text {ef }}$ & $3.87^{\mathrm{e}}$ & 0.699 \\
& Spring & $6.34^{\mathrm{bc}}$ & $5.18^{\mathrm{d}}$ & $6.94^{\mathrm{ab}}$ & \\
& Summer & $5.68^{\mathrm{cd}}$ & $7.38^{\mathrm{a}}$ & $6.75^{\mathrm{ab}}$ & \\
& Autumn & $2.72^{\mathrm{g}}$ & $3.08^{\mathrm{fg}}$ & $5.23^{\mathrm{d}}$ & \\
\hline
\end{tabular}

example, over-sowing of Westerwolds ryegrass in late summer can provide early winter grazing and high summer grazing capacities, Italian ryegrass over-sown during early autumn will provide spring fodder when Westerwolds ryegrass-kikuyu pastures support fewer animals, and late autumn over-sowing can be allocated to perennial ryegrass. Grazing capacity should, however, be considered in conjunction with seasonal changes in botanical composition and nutritive value when doing fodder-flow planning within ryegrass-kikuyu pasture system (van der Colf et al. 2015). Producers do not have the option of increasing or decreasing animal numbers according to pasture supply, and as such will not use the grazing capacities of this study in their current form to manage animal numbers. However, the monthly and seasonal grazing capacities give an important indication of the feed shortfall and surplus that will occur on kikuyu-ryegrass pasture if the mean stocking rate (animals per hectare) is known. This can allow for adequate planning for pasture conservation practices to occur during periods when pasture supply exceeds demand and timeous purchasing/production of supplementary forages.

\section{Milk production per animal}

The milk production, milk composition, live weight change and body condition score change of cows grazing kikuyu over-sown with Italian, Westerwolds or perennial ryegrass during years 1 and 2 is shown in Table 4 and Table 5, respectively.

The three kikuyu-based pasture systems had an average daily milk production between 15.9 and $16.1 \mathrm{~kg} \mathrm{cow}^{-1}$ during year 1 and between 16.1 and $17.7 \mathrm{~kg} \mathrm{cow}^{-1}$ during year 2 . These values compare favourably with those of Botha (2003) of between 14 and $17.2 \mathrm{~kg} \mathrm{cow}^{-1} \mathrm{~d}^{-1}$ for Jersey cows grazing annual ryegrass-kikuyu pastures. The daily milk production of cows grazing kikuyu over-sown with Italian, Westerwolds or perennial ryegrass was also similar to the daily milk production (17.2 to $18.7 \mathrm{~kg} \mathrm{cow}^{-1} \mathrm{~d}^{-1}$ ) of dairy cows grazing pure ryegrass stands in the same region (Meeske et al. 2009). The latter is unexpected, since the milk production per cow from kikuyu is notoriously low (Marais 2001) and the pastures contained an appreciable kikuyu component from spring onwards (van der Colf et al. 2015). The daily milk yield and 305 -day milk production of cows grazing Italian, Westerwolds or perennial ryegrass-kikuyu did not differ $(P>0.05)$ from each other during year 1 . During year 2 the 305 -day milk production of perennial ryegrass-kikuyu was lower $(P<0.05)$ than for Italian or Westerwolds ryegrass-kikuyu. The 305-day FCM milk production of perennial ryegrass-kikuyu was lower $(P<0.05)$ than Italian ryegrass-kikuyu during year 1 and lower $(P<0.05)$ than Italian and Westerwolds ryegrasskikuyu during year 2. Although Lowe et al. (1999) reported that there were no significant differences between the 300-day milk production of cows grazing pure swards based on perennial or Italian ryegrass, daily milk yield from the cows grazing Italian ryegrass pastures was almost $2 \mathrm{~L}$ lower per cow per day than for cows grazing perennial ryegrass pastures.

Although the butterfat (BF) percentage of the three treatments did not differ $(P>0.05)$ during year 1 or year 2 , cows grazing kikuyu over-sown with perennial ryegrass 
did have a lower $(P<0.05)$ production of BF per lactation (kilograms BF per cow). Studies based on pure stands of Italian or perennial ryegrass also did not report differences in the $\mathrm{BF}$ content of dairy cows grazing these two pasture types (Lowe et al. 1999). The BF contents of all three treatments (between $4.63 \%$ and $4.94 \%$ during year 1 and between $4.40 \%$ and $4.47 \%$ during year 2 ) were above values for $\mathrm{BF}(3.89 \%)$ recorded for supplemented Holsteins grazing kikuyu (Reeves et al. 1996). The BF contents were also higher than the $3.6 \% \mathrm{BF}$ reported for unsupplemented Holsteins grazing kikuyu at 30 -day grazing intervals (Henning et al. 1995). The lower BF percentages reported by these authors is most likely a result of breed differences, since Jerseys cows produce milk with a higher BF content $(4.43 \%)$ than Holsteins (3.54\%) (de Villiers et al. 2000). The only data that could be found in the literature for similar pastures grazed by Jersey cows were those of Botha et al. (2008b). The BF content of kikuyu-ryegrass pastures investigated here were similar to values of between $4.13 \%$ and $4.79 \%$ reported during the study by Botha et al. (2008b).

The milk protein content (\%) of perennial ryegrass-kikuyu was lower $(P<0.05)$ than Italian ryegrass-kikuyu during year 1 . The higher 305-day milk production of perennial

Table 4: Milk production, milk composition, live weight change and body condition score ${ }^{1}$ change of cows grazing kikuyu over-sown Italian, Westerwolds and perennial ryegrass for year 1 . Means in the same row with different superscript letters differed significantly at $\mathrm{P}<0.05$. LSD (0.05) compares within row over treatments. $\mathrm{FCM}=$ fat-corrected milk

\begin{tabular}{|c|c|c|c|c|}
\hline \multirow{2}{*}{ Parameter } & \multicolumn{3}{|c|}{ Treatment } & \multirow{2}{*}{$\operatorname{LSD}(0.05)$} \\
\hline & Italian-kikuyu & Westerwolds-kikuyu & Perennial-kikuyu & \\
\hline Daily milk production $\left(\mathrm{kg} \mathrm{cow}^{-1} \mathrm{~d}^{-1}\right)$ & $15.9^{\mathrm{a}}$ & $16.0^{\mathrm{a}}$ & $16.1^{\mathrm{a}}$ & 1.02 \\
\hline 305-day milk production $\left(\mathrm{kg} \mathrm{cow}^{-1}\right)$ & $4864^{a}$ & $4864^{a}$ & $4905^{a}$ & 311.2 \\
\hline 305-day 4\% FCM production $\left(\mathrm{kg} \mathrm{cow}^{-1}\right)$ & $5551^{\mathrm{ab}}$ & $5670^{a}$ & $5352^{\mathrm{b}}$ & 276.7 \\
\hline Butterfat production $\left(\mathrm{kg} \mathrm{cow}^{-1}\right)$ & $241^{a}$ & $247^{a}$ & $226^{b}$ & 14.0 \\
\hline Butterfat content (\%) & $4.94^{\mathrm{a}}$ & $4.97^{\mathrm{a}}$ & $4.63^{\mathrm{a}}$ & 0.384 \\
\hline Protein production $\left(\mathrm{kg} \mathrm{cow}^{-1}\right)$ & $185^{\mathrm{a}}$ & $186^{a}$ & $178^{a}$ & 9.9 \\
\hline Protein content (\%) & $3.84^{\mathrm{a}}$ & $3.75^{\mathrm{ab}}$ & $3.64^{\mathrm{b}}$ & 0.167 \\
\hline Milk solids production $\left(\mathrm{kg} \mathrm{cow}^{-1}\right)$ & $427^{a}$ & $433^{a}$ & $404^{b}$ & 21.6 \\
\hline Lactose content $(\%)$ & $4.64^{\mathrm{a}}$ & $4.66^{\mathrm{a}}$ & $4.66^{a}$ & 0.063 \\
\hline Milk urea nitrogen $\left(\mathrm{mg} \mathrm{dL}^{-1}\right)$ & $13.1^{\mathrm{ab}}$ & $12.9^{\mathrm{b}}$ & $14.1^{\mathrm{a}}$ & 1.27 \\
\hline Somatic cell count $\left(1000 \mathrm{~mL}^{-1}\right)$ & $215^{a}$ & $225^{a}$ & $213^{a}$ & 120.3 \\
\hline Body weight $_{\text {start }}(\mathrm{kg})$ & $353^{a}$ & $378^{a}$ & $357^{a}$ & 33.5 \\
\hline Body weight $_{\text {end }}(\mathrm{kg})$ & $396^{a}$ & $423^{a}$ & $408^{a}$ & 30.5 \\
\hline Body weight $_{\text {change }}(\mathrm{kg})$ & $42.6^{a}$ & $45.2^{\mathrm{a}}$ & $51.1^{\mathrm{a}}$ & 21.82 \\
\hline Body condition score start $^{1}$ & $2.22^{b}$ & $2.18^{b}$ & $2.45^{\mathrm{a}}$ & 0.229 \\
\hline Body condition score end $^{1}$ & $2.55^{a}$ & $2.58^{a}$ & $2.46^{a}$ & 0.316 \\
\hline Body condition score change $^{1}$ & $0.33^{a}$ & $0.40^{\mathrm{a}}$ & $0.02^{b}$ & 0.293 \\
\hline
\end{tabular}

${ }^{1}$ Five point system where 1 is thin and 5 is fat

Table 5: Milk production, milk composition, live weight change and body condition score ${ }^{1}$ change of cows grazing kikuyu over-sown with Italian, Westerwolds and perennial ryegrass for year 2 . Means in the same row with different superscript letters differed significantly at $P<0.05$. LSD (0.05) compares within row over treatments. FCM $=$ fat-corrected milk

\begin{tabular}{|c|c|c|c|c|}
\hline \multirow{2}{*}{ Parameter } & \multicolumn{3}{|c|}{ Treatment } & \multirow{2}{*}{$\operatorname{LSD}(0.05)$} \\
\hline & Italian-kikuyu & Westerwolds-kikuyu & Perennial-kikuyu & \\
\hline Daily milk production $\left(\mathrm{kg} \mathrm{cow}^{-1} \mathrm{~d}^{-1}\right)$ & $17.7^{a}$ & $17.1^{\mathrm{ab}}$ & $16.1^{\mathrm{b}}$ & 1.26 \\
\hline 305-day milk production (kg cow $\left.{ }^{-1}\right)$ & $5394^{a}$ & $5206^{a}$ & $4913^{b}$ & 383.7 \\
\hline 305-day $4 \%$ FCM production $\left(\mathrm{kg} \mathrm{cow}^{-1}\right)$ & $5773^{a}$ & $5769^{a}$ & $5182^{\mathrm{b}}$ & 358.0 \\
\hline Butterfat production $\left(\mathrm{kg} \mathrm{cow}^{-1}\right)$ & $241^{a}$ & $246^{a}$ & $214^{\mathrm{b}}$ & 17.9 \\
\hline Butterfat content (\%) & $4.50^{a}$ & $4.47^{a}$ & $4.40^{\mathrm{a}}$ & 0.380 \\
\hline Protein production $\left(\mathrm{kg} \mathrm{cow}^{-1}\right)$ & $191^{\mathrm{a}}$ & $187^{a}$ & $173^{b}$ & 13.0 \\
\hline Protein content $(\%)$ & $3.54^{a}$ & $3.61^{\mathrm{a}}$ & $3.53^{a}$ & 0.146 \\
\hline Milk solids production (kg cow $\left.{ }^{-1}\right)$ & $432^{a}$ & $433^{a}$ & $387^{b}$ & 27.5 \\
\hline Lactose content $(\%)$ & $4.61^{\mathrm{a}}$ & $4.63^{a}$ & $4.67^{a}$ & 0.080 \\
\hline Milk urea nitrogen $\left(\mathrm{mg} \mathrm{dL}^{-1}\right)$ & $19.5^{\mathrm{a}}$ & $19.5^{\mathrm{a}}$ & $18.3^{b}$ & 1.234 \\
\hline Somatic cell count $\left(1000 \mathrm{~mL}^{-1}\right)$ & $230^{a}$ & $242^{a}$ & $250^{a}$ & 128.4 \\
\hline Body weight $_{\text {start }}(\mathrm{kg})$ & $383^{a}$ & $402^{\mathrm{a}}$ & $368^{a}$ & 39.61 \\
\hline Body weight $_{\text {end }}(\mathrm{kg})$ & $414^{a}$ & $424^{a}$ & $383^{a}$ & 30.8 \\
\hline Body weight $_{\text {change }}(\mathrm{kg})$ & $31.0^{\mathrm{a}}$ & $22.2^{\mathrm{a}}$ & $15.0^{\mathrm{a}}$ & 38.2 \\
\hline Body condition score start $^{1}$ & $2.12^{a}$ & $2.17^{a}$ & $2.10^{\mathrm{a}}$ & 0.194 \\
\hline Body condition score $e_{\text {end }} 1$ & $2.43^{a}$ & $2.48^{a}$ & $2.22^{\mathrm{a}}$ & 0.314 \\
\hline Body condition score change $^{1}$ & $0.32^{\mathrm{a}}$ & $0.32^{\mathrm{a}}$ & $0.12^{\mathrm{a}}$ & 0.391 \\
\hline
\end{tabular}

\footnotetext{
${ }^{1}$ Five point system where 1 is thin and 5 is fat
} 
ryegrass-kikuyu during year 1 , however, cancelled out the effect of a lower protein content and, as such, the kilograms protein per lactation was similar $(P>0.05)$ for all kikuyuryegrass pastures during year 1 . During year 2 the opposite occurred, with the lower $(P<0.05)$ 305-day milk production of the perennial ryegrass-kikuyu pastures resulting in lower $(P<0.05)$ kilograms protein per lactation produced by the this pasture system than by the Italian and Westerwolds ryegrass-kikuyu systems, regardless of milk protein content for grazing animals being similar $(P<0.05)$ for all three pastures. The milk protein content (between $3.55 \%$ and $3.88 \%$ ) of the three kikuyu-based systems was similar or slightly higher to those recorded by Henning et al. (1995) for cows grazing kikuyu (3.6\%). Only the Italian ryegrasskikuyu treatment during year 1 reached similar protein percentages of $3.82 \%$ and $3.85 \%$ for Italian and perennial ryegrass-based pastures, respectively (Lowe et al. 1999). All treatments achieved similar or higher protein contents of between $3.42 \%$ and $3.59 \%$ reported for annual ryegrasskikuyu pastures in the same region (Botha 2003).

The lactose content (\%) of cows grazing the three ryegrass-kikuyu pastures did not differ $(P>0.05)$ between treatments. Milk lactose content is the least variable milk component and is essentially a constant $4.85 \%$ of milk, varying only slightly with breed and milk protein concentration (NRC 2001). The somatic cell contents of all treatments were similar during year 1 and year 2 , and were below the value of $>300$ cells $\mathrm{mL}^{-1}$ considered as abnormal for cows' milk (de Villiers et al. 2000).

The total milk solids production of perennial ryegrasskikuyu was lower $(P<0.05)$ than for Italian and Westerwolds ryegrass-kikuyu during both years. Milk solids content has been reported to decrease with lowered protein and energy intake, as well as increased fibre intake (de Villiers et al. 2000). This is unlikely to be the reason for the lower milk solids production observed for the perennial ryegrass-kikuyu pastures, since the three pasture treatments did not differ in terms of seasonal crude protein (CP) content, except during winter and autumn in year 1, when perennial ryegrass-kikuyu pasture had a lower $(P<0.05) \mathrm{CP}$ content than Italian ryegrass-kikuyu pastures (van der Colf et al. 2015). In addition, the neutral detergent fiber content of perennial ryegrass-kikuyu pastures was similar $(P>0.05)$ to the other kikuyu-ryegrass pastures throughout the study (van der Colf et al. 2015). The only contributing factor could thus have been metabolisable energy (ME) content, with the ME content of perennial ryegrass-kikuyu lower $(P<0.05)$ than that of Italian ryegrass-kikuyu during summer and autumn during year 1 .

The milk urea nitrogen (MUN) content $\left(\mathrm{mg} \mathrm{dL}^{-1}\right)$ of all three ryegrass-kikuyu pasture systems was between 12.9 and $14.1 \mathrm{mg} \mathrm{dL}^{-1}$ during year 1 and fell within the range of 12 to $18 \mathrm{mg} \mathrm{dL}^{-1}$ recommended by Harris (1996) for cows achieving a milk protein content above $3.2 \%$. According to Harris (1996), this indicates that animals received a diet with a balanced amino acid and carbohydrate content. During year 2, the MUN contents of all three pasture systems were above the recommended levels (between 18.3 and $19.5 \mathrm{mg} \mathrm{dL}^{-1}$ ), indicating that the protein intake of the experimental animals was in excess of requirements or that there was a deficient level of energy in the diet (Harris
1996). Trevaskis and Fulkerson (1999) hypothesised that the high nitrogen/water-soluble carbohydrate (WSC) ratio often found in kikuyu may increase MUN levels, primarily because cows are unable to metabolise the large pool of ammonia that accumulates under certain circumstances of grazing. Since WSC content was not measured during this study, it could not be determined if this was the case here. The very low ME content of all pasture treatments during summer and autumn in year 2 could, however, have been a contributing factor.

Cows grazing kikuyu over-sown with Italian, Westerwolds or perennial ryegrass had similar $(P>0.05)$ start and end body weights and did not differ $(P>0.05)$ in terms of body weight change during either year 1 or year 2 . Cows on all the treatments gained weight from calving up until the end of the experimental period/drying off during both years. During year 1 the cows grazing the perennial ryegrasskikuyu started their lactation at a higher $(P<0.05)$ body condition score (BCS), but all pasture treatments had similar $(P>0.05)$ BCS at the end of the lactation. As a result, the perennial ryegrass-kikuyu pasture treatment had a lower $(P<0.05)$ gain in BCS than the Italian and Westerwolds ryegrass-kikuyu pasture treatments. Although a higher BCS at calving has been linked to higher 4\% FCM yields, the BCS of perennial ryegrass-kikuyu was not high enough to elicit this response, since the increase is most marked at a BCS of 3 (Roche et al. 2007). During year 2 all three pasture treatments had similar $(P>0.05) \mathrm{BCS}$ at the end and start of the experimental period, with no differences $(P>0.05)$ between treatments in terms of BCS change during lactation.

Cows grazing perennial ryegrass-kikuyu pastures tended to have lower milk production parameters than when kikuyu was over-sown with Italian or Westerwolds ryegrass. This is irrespective of the fact that it was found that the nutritive value of perennial ryegrass was similar to that of the other treatments during the majority of the study period (van der Colf et al. 2015). The shorter winter grazing period of the perennial ryegrass, when pastures consisted predominately of ryegrass, and longer grazing period during autumn, when pastures consisted of primarily kikuyu (van der Colf et al. 2015), could be a potential contributor to this finding.

\section{Milk production per hectare}

The mean annual grazing capacity, milk production and milk solids production per hectare of kikuyu over-sown with Italian, Westerwolds and perennial ryegrass during years 1 and 2 is shown in Table 6.

The perennial ryegrass-kikuyu pasture achieved a higher $(P<0.05)$ mean annual grazing capacity and milk production per hectare than Italian and Westerwolds ryegrasskikuyu during years 1 and 2 . This is irrespective of the lower milk production from cows grazing perennial ryegrasskikuyu pastures during year 2. Within the three ryegrasskikuyu systems evaluated here, where relatively small differences were apparent in milk yield per cow, stocking rate was the more important factor influencing milk production per hectare. The FCM production per hectare and milk solids per hectare of perennial ryegrass-kikuyu was also higher $(P<0.05)$ during year 2 , but was similar $(P>0.05)$ for all ryegrass-kikuyu pasture systems during year 1 . The 
Table 6: Mean annual grazing capacity, milk production and milk solids per hectare for kikuyu over-sown with Italian, Westerwolds and perennial ryegrass during years 1 and year 2 . Means in the same row with different superscript letters differed significantly at $P<0.05$. LSD (0.05) compares within row across treatments. FCM $=$ fat-corrected milk

\begin{tabular}{|c|c|c|c|c|c|}
\hline \multirow{2}{*}{ Year } & \multirow{2}{*}{ Parameter } & \multicolumn{3}{|c|}{ Treatment } & \multirow{2}{*}{ LSD $(0.05)$} \\
\hline & & Italian-kikuyu & Westerwolds-kikuyu & Perennial-kikuyu & \\
\hline \multirow[t]{3}{*}{1} & Grazing capacity (cows ha-1) ${ }^{1}$ & $6.44^{\mathrm{b}}$ & $6.49^{\mathrm{b}}$ & $6.93^{a}$ & 0.273 \\
\hline & Milk production $\left(\mathrm{kg} \mathrm{ha}^{-1}\right)$ & $30446^{b}$ & $29761^{b}$ & $32288^{a}$ & 1539.9 \\
\hline & Milk solids production ( $\mathrm{kg} \mathrm{MS} \mathrm{ha-1)}^{-1}$ & $2627^{a}$ & $2566^{a}$ & $2639^{a}$ & 128.5 \\
\hline \multirow[t]{2}{*}{2} & Grazing capacity (cows ha-1 $)^{1}$ & $5.34^{\mathrm{b}}$ & $5.52^{\mathrm{b}}$ & $5.96^{a}$ & 0.350 \\
\hline & Milk production $\left(\mathrm{kg} \mathrm{ha}^{-1}\right)$ & $28073^{b}$ & $27032^{\mathrm{b}}$ & $31385^{a}$ & 1253.4 \\
\hline
\end{tabular}

${ }_{1}^{1}$ For the 10-month period when experimental animals were on the experimental area

mean annual grazing capacities of all treatments were lower than annual grazing capacities of 6.67 to 9.01 cows ha $^{-1}$ reported by Botha et al. (2008b) for annual ryegrass-kikuyu pastures. However, the pastures during the study by Botha et al. (2008b) were grazed for a shorter period than reported here. The milk production per hectare of all three ryegrasskikuyu systems compared favourably with production rates of between 25953 and $38406 \mathrm{~kg}$ milk ha-1 observed in other studies where dairy cows grazed annual ryegrasskikuyu pastures in the Southern Cape (Botha et al. 2008b). Farina (2009) reported that, depending on the management practices applied, annual milk production varied between 20895 and $34583 \mathrm{~L} \mathrm{ha}^{-1}$ for Holstein cows grazing annual ryegrass-kikuyu pasture. The annual ryegrass-kikuyu system based on maintaining a higher stocking rate was observed to result in higher milk production per hectare than when management focused on obtaining a high milk production per cow. This agrees with the finding in our study that by maintaining a higher grazing capacity over time, the perennial ryegrass-kikuyu pasture obtained a higher milk production per hectare than the other pasture treatments.

\section{Conclusions}

The grazing capacities of the three kikuyu-based pasture systems varied over months and seasons, with the grazing capacity of all three treatments lower during winter and autumn than during spring and summer. Kikuyu over-sown with perennial ryegrass had more evenly distributed seasonal grazing capacities than kikuyu over-sown with Italian or Westerwolds ryegrass. A strategic fodder flow plan based on combining the three kikuyu-ryegrass systems could potentially be used to further reduce large variation in grazing capacity over seasons. Additional strategies will, however, be required to alleviate fodder flow shortages that may occur during winter when grazing capacities are low.

The perennial ryegrass-kikuyu pasture treatment had a lower 305-day FCM production than the Westerwolds ryegrass-kikuyu pasture during years 1 and 2 . In addition, the perennial ryegrass-kikuyu treatment had lower butterfat and milk solids production per lactation than the Italian and Westerwolds ryegrass-kikuyu treatments during both years. However, due to the higher annual grazing capacity achieved by the perennial ryegrass-kikuyu pasture during years 1 and 2, it achieved a higher milk production per hectare during both years. During year 2 the perennial ryegrass-kikuyu pastures achieved a higher milk solids and FCM production per hectare than the Italian ryegrasskikuyu and Westerwolds ryegrass-kikuyu pastures.

It is thus concluded that the perennial ryegrass-kikuyu provided a more even fodder-flow availability and achieved higher animal production per hectare, primarily because it supported more animals per hectare than the kikuyu over-sown with Italian or Westerwolds ryegrass during both years. An economic analysis and comparison is, however, recommended to identify the most profitable kikuyuryegrass system in order to give consideration to the input costs required for, and income generated by, each system.

\section{References}

Beyers CP. 1973. Bemesting van aangeplante weidings. Winterreën Spesiale Uitegawe 5: 54-59.

Botha PR. 1995. Die bestuur van kikoejoe wat gedurende die winter met eenjarige weigewasse versterk word. Proceedings of Outeniqua Research Farm Information Day 1995. George, South Africa.

Botha PR. 2002. Die gebruik van vogspanningmeters vir besproeiingskedulering by weidings. In: Weidingskursus 2002 Inligtingsbundel. George: Suid-Kaap Landbouontwikkelinsentrum, Departement Landbou Wes-Kaap. pp 141-149.

Botha PR. 2003. Die produksiepotensiaal van oorgesaaide kikoejoeweiding in die gematigde kusgebied van die Suid-Kaap. $\mathrm{PhD}$ thesis, University of the Free State, South Africa.

Botha PR. 2009. Factors influencing the persistence and production potential of kikuyu (Pennisetum clandestinum) over-sown with different ryegrass and clover species in the southern Cape. Elsenburg Journal 3: 4-9.

Botha PR, Gerber HS, Zulu B. 2008c. Die seisoenale droëmateriaalproduksie van Kropaargras, Swenkgras en verskillende meeren eenjarige raaigrasspesies. In: Proceedings of Outeniqua Research Farm Information Day 2008. George: Western Cape Department of Agriculture. pp 12-21.

Botha PR, Meeske R, Snyman HA. 2008a. Kikuyu over-sown with ryegrass and clover: dry matter production, botanical composition and nutritional value. African Journal of Range and Forage Science 25: 93-101.

Botha PR, Meeske R, Snyman HA. 2008b. Kikuyu over-sown with ryegrass and clover: grazing capacity, milk production and milk composition. African Journal of Range and Forage Science 25: 103-110. 
Botha PR, Zulu LB. 2013. The production potential of Italian and Westerwolds ryegrass planted at different planting dates. In: Research Article Compilation Outeniqua Research Farm 2008-2013. Elsenburg: Western Cape Department of Agriculture. pp 64-77.

Bransby DI, Tainton NM. 1977. The disc pasture meter: possible applications in grazing management. Proceedings of the Grassland Society of South Africa 12: 115-118.

Caton JS, Dhuyvetter DV. 1997. Influence of energy supplementation on grazing ruminants: requirements and responses. Journal of Animal Science 75: 533-542.

Clark DA. 2010. Contribution of farmlet scale research in $\mathrm{New}$ Zealand and Australia to improved dairy farming system. In: Edwards GR, Bryant RH (eds), Proceedings of the 4th Australasian Dairy Science Symposium 2010, 31 August2 September 2010, Lincoln University, Christchurch, New Zealand. Lincoln: Lincoln University. pp 112-124.

Coetzee K (compiler). 2014. Lacto Data vol. 17 no. 1. Pretoria: Milk Producers' Organisation.

de Villiers P, Petzer IM, Erasmus LJ. 2000. The use of milk recording information as a herd management tool. In: Loubser LFB, Banga CB, Scholtz MM, Hallowell GJ (eds), Dairy herd improvement in South Africa. Irene: ARC-Animal Improvement Institute. pp 53-64.

Farina S. 2009. Strategies to maximise intake per ha in a pasture based system. University of Sydney Dairy Research Foundation: Current Topics in Dairy Production 14: 33-42.

Fulkerson WJ. 1997. Use of the rising plate meter to allocate pasture. Research to Farm. Wollongbar: Wollongbar Agricultural Institute, New South Wales Department of Agriculture.

Fulkerson WJ, Nandra KS, Clark CF, Barchia I. 2006. Effect of cereal-based concentrates on productivity of Holstein-Friesian cows grazing short-rotation ryegrass (Lolium multiflorum) or kikuyu (Pennisetum clandestinum) pastures. Livestock Science 103: 85-94.

García SC, Islam MR, Clark CEF, Martin PM. 2014. Kikuyu-based pasture for dairy production: a review. Crop and Pasture Science 65: 787-797.

Harris B Jr. 1996. Using milk urea nitrogen and blood urea values as management tools. In: Lyons TP, Jacques KA (eds), Biotechnology in the feed industry: proceedings of Alltech's 12th annual symposium. Loughborough: Nottingham University Press. pp 75-81 [cited by de Villiers et al. 2000].

Henning WP, Barnard HH, Venter JJ. 1995. Effect of grazing cycle on the milk production of cows on kikuyu pasture. South African Journal of Animal Science 25: 7-12.

IDF (International Dairy Federation). 1996. Determination of fat, protein and lactose content - guide for operation of mid-infra-red instruments. Standard 141B. Brussels: IDF.

Little TM, Hills FJ. 1978. Agricultural experimentation: design and analysis. New York: John Wiley and Sons.

Lowe KF, Bowdler TM, Casey ND, Moss RJ. 1999. Performance of temperate perennial pastures in the Australian tropics 2. Milk production. Australian Journal of Experimental Agriculture 39: 677-683.

Marais JP. 2001. Factors affecting the nutritive value of kikuyu grass
(Pennisetum clandestinum) - a review. Tropical Grasslands 35: 65-84.

Meeske R, Rothauge A, van der Merwe GD, Greyling JF. 2006. The effect of concentrate supplementation on the productivity of grazing Jersey cows on a pasture based system. South African Journal of Animal Science 36: 105-110.

Meeske R, Botha PR, van der Merwe GD, Greyling JF, Hopkins C, Marais JP. 2009. Milk production potential of two ryegrass cultivars with different total-nonstructural carbohydrate contents. South African Journal of Animal Science 39: 15-21.

Miles N. 1997. Responses of productive and unproductive kikuyu pastures to top-dressed nitrogen and phosphorous fertiliser. African Journal Range and Forage Science 14: 1-6.

NRC (National Research Council). 2001. Nutrient requirements of dairy cattle (7th revised edn). Washington, DC: National Academy Press.

Reeves M, Fulkerson WJ, Kellaway RC. 1996. Production response of dairy cows grazing well managed kikuyu (Pennisetum clandestinum) pastures to energy and protein supplementation. Australian Journal of Experimental Agriculture 36: 763-770.

Roche JR, Dillon PG, Stockdale CR, Baumgard LH, Van Baale MJ. 2004. Relationships among International body condition scoring systems. Journal of Dairy Science 87: 3076-3079.

Roche JR, Lee JM, MacDonald KA, Berry DP. 2007. Relationship among body condition score, body weight, and milk production variables in pasture based dairy cows. Journal of Dairy Science 90: 3802-3815.

SAS 1999. SAS/STAT user's guide, version 8, 1st printing, vol. 2. Cary: SAS Institute.

Shapiro SS, Wilk MB. 1965. An analysis of variance test for normality (complete samples). Biometrika 52: 591-611.

Stockdale CR. 1984. Evaluation of techniques for estimating the yield of irrigated pastures intensively grazed by dairy cows. II. The rising plate meter. Australian Journal of Experimental Agriculture and Animal Husbandry 24: 305-311.

Trevaskis LM, Fulkerson WJ. 1999. The relationship between various animal and management factors and milk urea, and its association with reproductive performance of dairy cows grazing pasture. Livestock production Science 57: 255-265.

van der Colf J, Botha PR. 2014. The production potential of perennial ryegrass and perennial ryegrass hybrids in the southern Cape of South Africa. In: Proceedings of the 49th Annual Congress of the Grassland Society of Southern Africa, 20-25 July 2014, Bloemfontein, South Africa. pp 93-94.

van der Colf J, Botha PR, Meeske R, Truter WF. 2015. Seasonal dry matter production, botanical composition and forage quality of kikuyu over-sown with annual or perennial ryegrass. African Journal of Range and Forage Science. DOI: /10.2989/10220119 .2015.1018945.

van Houtert MJF, Sykes AR. 1999. Enhancing the profitability of pasture based dairy production in the humid tropics through improved nutrition. Preventative Veterinary Medicine 38: 147-157.

Zulu LB, van der Colf J, Botha PR. 2014. The production potential of annual ryegrass cultivars in the souther Cape. In: Proceedings of the 49th Annual Congress of the Grassland Society of Southern Africa, 20-25 July 2014, Bloemfontein, South Africa. p 97. 